\title{
Phytochemical screening and evaluation of anti-microbial and anti-oxidant activity of Elettaria cardamom (Cardamom)
}

\author{
Shabana Bano, Nashrah Ahmad and A. K. Sharma \\ Department of Zoology, University of Lucknow, Lucknow- 226007 (U. P.), INDIA \\ *Corresponding author. E-mail: shabana700@gmail.com
}

Received: April 29, 2016; Revised received: July 11, 2016; Accepted: November 1, 2016

\begin{abstract}
The present study deals with the phytochemical screening and evaluation of antibacterial and antioxidant activities from the crude methanol extract of the seeds of cardamom, Elettaria cardamom. Crude methanol extract was investigated for their antibacterial activity against Enteropathogenic E. coli (EPEC), Listeria monocytogenes, Bacillus pumilus and Escherichia coli. The extract showed maximum zone of inhibition (20.3 mm) against $E P E C$, however, the antibacterial potential of the extract was slightly lesser against normal $E$. coli (19 mm). It showed moderate anti-bacterial activity against $L$. monocytogenes and $B$. pumilus. Dose-dependent increase in antioxidant activity was also noticed in crude extract as measured by DPPH free radical scavenging assay. Thus, our study reports various phytochemicals in the seeds of cardamom with antioxidant and antibacterial potential.
\end{abstract}

Keywords: Anti-microbial activity, Anti-oxidant activity, Cardamom, DPPH

\section{INTRODUCTION}

Since ancient times, plants have been utilized for their medicinal properties. Use of medicinal plants is an important part of traditional as well as modern system of medicine (Bruneton et al., 2001). India is particularly rich in naturally occurring plant drugs which have enormous potential pharmacological activities (Srinivasan et al., 2001). Cardamom is one such plant with known medicinal properties. It is often known as the "Queen of Spices" and is often used as a cooking ingredient due to its pleasing aroma and taste (Bhattacharjee et al., 2013). The cardamom plant is a medium-sized herbaceous perennial, about 2 to 5 meters tall. It is the native of Western Ghats in South West India and cardamoms are the dried fruits or capsules of the plant.

Essential oil of cardamom has been commonly used in traditional medicine since a long time. A number of bioactive compounds have been found in cardamom (Bhattacharjee et al., 2013). Cardamom contains flavonoids like quercetin, kaempferol, luteolin and pelargonidin (Sultana et al., 2010). Extracts from cardamom have shown antibacterial (Supriya et al., 2010; Hero et al., 2012 Naveed et al., 2013) and antioxidant properties (Nair et al., 1998; I.P.S Kapoor et al., 2008; Jayawardena et al., 2015). Enteropathogenic Escherichia coli (EPEC) is one of the Escherichia coli pathotypes. It is known to be important diarrhoea pathogen of young children. EPEC are gram-negative, rod-shaped bacteria and are among the most important pathogens infecting children both in developing countries and developed countries (Baliere et al., 2016). Listeria monocytogenes is a rod-shaped, Gram-positive bacte- rium. It is the agent of listeriosis, which is a serious infection caused by eating food contaminated with $L$. monocytogenes (Shegarfi et al., 2016). B. pumilus is a Gram-positive, rod shaped and aerobic bacteria. It is found in soils and some reside in the root area of some plants (Grass et al., 2016). E.coli is a gram negative, rod shaped bacteria that is commonly found in the intestine of warm-blooded organisms.

Antioxidants are part of the body's defence system against free radicals attack. Antioxidants are involved in the prevention of cellular damage which leads to pathways of aging and cancer. A number of antioxidants have been derived from the plant sources (Kogure et al., 2004). The present study demonstrates potent antibacterial activity of cardamom extract against some pathogenic and non pathogenic Gram positive $L$. monocytogenes, B. pumilus) as well as Gram negative bacteria $E P E C, E$. coli]. We have also evaluated the antioxidant activity of methanol extract of cardamom seeds by using DPPH radical scavenging assay.

\section{MATERIALS AND METHODS}

Plant material: Cardamom fruits were purchased from local market of Babuganj, Lucknow and were identified by Prof. Y.K. Sharma, Former Head, Department of Botany, University of Lucknow. Sample was washed under running tap water and dried at room temperature $\left(25^{\circ} \mathrm{C}\right)$. Cardamom fruit was opened with the help of forceps to obtain seeds. Only seeds of the cardamom fruit were used for this study. Seeds obtained from the fruit were grinded with the help of mortar and pestle, the produced powder was stored in 
plastics bags for further study.

Preparation of plant extracts: Dried cardamom seed powder was extracted with methanol in soxhlet extractor. $100 \mathrm{gms}$ of dried powder was mixed in 1 litre methanol for extraction. The soxhlet extraction setup was set at room temperature. Crude extract was filtered through Whatman No-1 using a Buchner funnel and thereafter concentrated with the help of rotary evaporator at vacuum at $40{ }^{\circ} \mathrm{C}$.

Extraction yield: $38.50 \mathrm{~g}$ of extract was obtained from $87.97 \mathrm{~g}$ of powdered cardamom seeds after concentration and drying of extracts. Percentage yield was calculated to be $43.76 \%$. The percentage of extraction yield was calculated by the following formula:-

Percentage of Yield $(\%)=\frac{\text { Amount of extract }(\mathrm{g})}{\text { Amount of dried part used }(\mathrm{g})} \times 100$ Phytochemical screening: Phytochemical analysis of the cardamom methanol extract was carried out to test for the presence of flavonoids, amino acids, saponins, alkaloids, phenols, tannins, terpenoids, quinone and glycoside as per the following protocols:

(i) Test for flavonoid: Test solution was treated with $10 \% \mathrm{NaOH}$. Formation of greenish brown colour indicates the presence of flavonoids (Edeoga et al., 2005). ii) Test for free amino acids: Test solution when boiled with $0.2 \%$ ninhydrin solution, formation of purple colour indicates the presence of free amino acids (Khandelwal et al., 2001) .

(iii) Test for saponin (Froth test): Test solution when added to water and shaken well, formation of frothing indicates the presence of saponin (Aiyelaagbe et al., 2009) .

(iv) Test for alkaloid: $1 \mathrm{ml}$ of test solution when treated with $1 \mathrm{ml}$ of Hagger's reagent, formation of yellow colour precipitate indicates the presence of alkaloid (Obadoni et al., 2001).

(v) Test for phenols: Test solution was treated to alcohol and ferric chloride formation of greenish yellow colour indicates the presence of phenols (Khandelwal et al., 2001).

(vi) Test for tannin: Test solution treated with $20 \%$ boiled water and $0.1 \% \mathrm{FeCl}_{3}$, formation of brownish green colour indicates the presence of tannin (Edeoga et al., 2005).

(vii) Test for terpenoids: Test solution was treated with chloroform and conc. $\mathrm{H}_{2} \mathrm{SO}_{4}$, formation of orange colour indicates the presence of terpenoids (Edeoga et al., 2005).

(viii) Test for quinones: If test solution when treated with $\mathrm{HCl}$ gives red precipitate, it indicates the presence of quinine (Khandelwal et al., 2001).

(ix) Test for glycoside: five millilitre of test sample when treated with $2 \mathrm{ml}$ of glacial acetic acid containing few drops of $\mathrm{FeCl}_{3}$ and $1 \mathrm{ml} \mathrm{H}_{2} \mathrm{SO}_{4}$ added, a brown layer at interfere indicates glycoside (Aiyelaagbe et al., 2009).

Determination of antimicrobial activity

Test microorganisms and bacterial culture: E.coli (NCIM 2065), B. pumilus (NCIM 9369) and L. mono- cytogenes (NCIM 5279) obtained from NCL Pune, were used to determine antibacterial activity. EPEC E 2347 was obtained from KGMU, Lucknow. The glycerol stock cultures of micro-organisms were maintained at $-80^{\circ} \mathrm{C}$. Working cultures were kept at $4^{\circ} \mathrm{C}$ and were periodically subcultured. The inocula of the micro-organisms were prepared by transferring a loopful of working culture into $9 \mathrm{ml}$ of sterilized LB media and incubated in incubator shaker at $37^{\circ} \mathrm{C}$ for 5 to $6 \mathrm{~h}$. The bacterial culture was compared with Mc-Farland turbidity standard and the culture that has attained 0.5 Mc-Farland units was used for the assay.

Well diffusion method: The antibacterial activity of cardamom extract was tested by using well diffusion technique as described by Agarry et al. (2005). LB agar plates were prepared by pouring $25 \mathrm{ml}$ autoclaved sterile LB Agar in sterile Petri plates $(90 \mathrm{~mm})$. Overnight cultures having .05 OD of above mentioned bacterial strains were swabbed over sterilised agar plates. A standard cork borer was used for creation of uniform $6 \mathrm{~mm}$ well on the surface of LB agar plates. Total 3 pores were made on plates, for positive control, negative control and one for sample. $50 \mathrm{mg}$ of concentrated methanol extract of cardamom was dissolved in $1 \mathrm{ml}$ of $0.5 \%$ of DMSO and $40 \mu \mathrm{l}$ of this extract was poured in one of the well. Streptomycin was chosen as positive control for antibacterial activity. $20 \mathrm{mg}$ streptomycin was dissolved in $1 \mathrm{ml} \mathrm{DMSO}$ and $40 \mu \mathrm{l}$ was poured in the second well as positive control. $40.5 \%$ of $40 \mu \mathrm{l}$ DMSO was poured in the third well as negative control. Whole set of experiment was done in triplicates and these plates were places at $37^{\circ} \mathrm{C}$ for overnight. The inhibition zone was calculated as mean $(n=3)$.

Determination of antioxidant activity

DPPH radical-scavenging: For determination of antioxidant activity of test sample DPPH radical scavenging reagent was used. DPPH-free radical scavenging capacity of cardamom extract was evaluated according to the method of Chen et al., (1995) with slight modifications. DPPH solution of $1 \mathrm{mM}$ concentration was prepared in methanol. Ascorbic acid was used as a positive control. Following concentrations of ascorbic acid was used: $25 \mu \mathrm{g} / \mathrm{ml}, 50 \mu \mathrm{g} / \mathrm{ml}, 100 \mu \mathrm{g} / \mathrm{ml}, 200 \mu \mathrm{g} /$ $\mathrm{ml}$ and $400 \mu \mathrm{g} / \mathrm{ml}$. $1 \mathrm{ml}$ of each sample was mixed with $1 \mathrm{ml}$ DPPH solution by shaking vigorously for $1 \mathrm{~min}$ by vortexing and then incubated in dark for 30 minutes. After incubation period of 30 minutes at $37^{\circ} \mathrm{C}$, absorbance of each sample $\left(\mathrm{A}_{\text {sample }}\right)$ at $517 \mathrm{~nm}$ were measured using UV spectrophotometer. Corresponding methanol blanks were taken. Similarly, following concentrations of cardamom extract were used: $25 \mu \mathrm{g} / \mathrm{ml}, 50 \mu \mathrm{g} / \mathrm{ml}, 100 \mu \mathrm{g} / \mathrm{ml}, 200 \mu \mathrm{g} / \mathrm{ml}$ and 400 $\mu \mathrm{g} / \mathrm{ml}$. Likewise, $1 \mathrm{ml}$ of each test sample was mixed with $1 \mathrm{ml}$ DPPH solution by shaking vigorously for $1 \mathrm{~min}$ by vortexing and then incubated in dark for 30 minutes. After incubation period of 30 minutes at $37^{\circ} \mathrm{C}$, absorbance of each test sample $\left(\mathrm{A}_{\text {sample }}\right)$ at 
$517 \mathrm{~nm}$ was measured using UV spectrophotometer. Corresponding methanol blanks were taken. The experiment was performed in triplicate. A negative control $\left(\mathrm{A}_{\text {control }}\right)$ was taken after adding DPPH solution to $1 \mathrm{ml}$ of methanol. Lower absorbance of the reaction mixture indicates higher radical scavenging activity (Biswas et al., 2010). The scavenging effect (\%) was measured by using the following formula:

Scavenging effect $(\%)=\left[1-\left(\mathrm{A}_{\text {sample }} / \mathrm{A}_{\text {control }}\right)\right] \times 100$

\section{RESULTS}

Phytochemical analysis: Phytochemical analysis of the methanol extract of cardamom demonstrated the presence of terpenoids as the major phytochemical (Table- 1). In addition to that, flavonoids and glycosides were also found in the extract.

Antibacterial activity: A preliminary antibacterial study of the cardamom extract is summarized in Table2. Well diffusion method revealed various degree of sensitivity by the test microorganisms against cardamom extract. Well diffusion method had demonstrated EPEC (20.3 mm zone of inhibition as compared to 26 $\mathrm{mm}$ zone of inhibition for positive control i.e. streptomycin) as the most sensitive organism for the cardamom extract followed by B. pumilus (19 $\mathrm{mm}$ zone of inhibition as compared to $25 \mathrm{~mm}$ zone of inhibition for positive control i.e. streptomycin). Moderate resistance was exhibited by L. monocytogenes (18.5 $\mathrm{mm}$ zone of inhibition as compared to $22 \mathrm{~mm}$ zone of inhibition for positive control i.e. streptomycin) and E. coli (16.5 $\mathrm{mm}$ zone of inhibition as compared to $20 \mathrm{~mm}$ zone of inhibition for positive control i.e. streptomycin). All experiments were performed in triplicate and the inhi- bition zone was calculated as mean $(n=3)$.

Antioxidant activity: The results on DPPH· radical scavenging activity of the cardamom extract along with the reference standard ascorbic acid are shown in Table- 3 .

\section{DISCUSSION}

Free radicals are known to have a number of pathological manifestations. It is the antioxidants that fight with the free radicals and protect from their harmful effects (Umamaheswari et al., 2008). In our study, various concentrations of methanol extract of cardamom were tested for their antioxidant activity using the DPPH radical scavenging assay. Significant antioxidant activity was observed in the cardamom extract. DPPH assay is a widely used method to estimate the free radical scavenging effect of plant extracts. It is based on the reduction of DPPH solution in the presence of antioxidant that results in the synthesis of non radical DPPH-H. In addition, phytochemical screening and evaluation of anti microbial activity were also carried out in our study. Among all the microbes tested, the most significant anti-microbial activity of cardamom extract was found against EPEC. Hero et al. (2012) have demonstrated the anti-microbial activity of cardamom extract against Staphylococcus aureus and Proteus mirabilis. While Islam et al. (2010) have demonstrated the anti-microbial activity of cardamom extract against 10 human pathogenic bacteria (Gram negative: Klebsiella pneumoniae, Pseudomonas aeruginosa, Salmonella typhi, Shigella dysenteriae, and Shigella sonnei as well as Gram positive: Staphylococcus aureus, Streptococcus- $\beta$-haemolytica, Bacillus subtilis, B. megaterium, and Sarcina lutea). Jebur

Table 1. Phytochemical analysis of cardamom methanol extract.

\begin{tabular}{|c|c|c|c|c|c|c|c|c|}
\hline Sample & Alkaloids & Flavonoids & Phenol & Glycoside & Saponins & Quinone & Tannins & Terpenoids \\
\hline $\begin{array}{l}\text { Cardamom } \\
\text { (Methanol } \\
\text { extract) }\end{array}$ & - & + & - & + & - & - & - & + \\
\hline
\end{tabular}

Table 2. Antibacterial activity of cardamom extract as measured by Well diffusion assay.

\begin{tabular}{lccc}
\hline Bacteria strain name & $\begin{array}{l}\text { Diameter of zone of inhi- } \\
\text { bition for cardamom } \\
\text { methanol extract } \mathbf{( ~ m m )}\end{array}$ & $\begin{array}{l}\text { Diameter of zone of inhi- } \\
\text { bition for positive control } \\
\text { i.e. Streptomycin ( } \mathbf{m m})\end{array}$ & $\begin{array}{l}\text { Diameter of zone of inhibi- } \\
\text { tion for negative control } \\
\text { i.e. DMSO }\end{array}$ \\
\hline (mm)
\end{tabular}

Table 3. $\%$ of inhibition of cardamom extract as measured by DPPH assay.

\begin{tabular}{|c|c|c|c|c|c|}
\hline & $\begin{array}{l}25 \mu g / 1 \text { concen- } \\
\text { tration }\end{array}$ & $\begin{array}{l}50 \mu g / 1 \text { concen- } \\
\text { tration }\end{array}$ & $\begin{array}{l}100 \mu g / l \text { con- } \\
\text { centration }\end{array}$ & $\begin{array}{l}200 \mu g / 1 \text { con- } \\
\text { centration }\end{array}$ & $\begin{array}{l}400 \mu \mathrm{g} / \mathrm{l} \text { con- } \\
\text { centration }\end{array}$ \\
\hline $\begin{array}{l}\text { \% of inhibition by ascorbic } \\
\text { acid (Positive control) }\end{array}$ & 76.63 & 80.98 & 87.55 & 88.87 & 91.53 \\
\hline $\begin{array}{l}\% \text { of inhibition by carda- } \\
\text { mom extract }\end{array}$ & 60.9 & 75.3 & 78.55 & 79.87 & 82.53 \\
\hline
\end{tabular}


et al. (2014) have evaluated antimicrobial activity of cardamom fruit extract, leaves and oil against Staphylococcus aureus, Streptococcus pneumonia, S.epidermidis, P. aeroginosa, K. pneumonia, Proteus mirabilis, Enterobacter spp. Acinetobacter, E. coli, Serretia spp. and Salmonella typhi. Chawla et al., (2014) have studied the antimicrobial activity of cardamom against Bacillus and pseudomonas. Our results are in accordance with Mishra et al., (2010) who had also demonstrated the antimicrobial activity of cardamom against, E. coli using ethanol and aqueous extracts of cardamom. We have demonstrated antimicrobial activity of cardamom extract against EPEC, L. monocytogenes, B. pumilus and E. coli. Antimicrobial activity of cardamom is due to the presence of various chemical compounds like volatile oils, alkaloids, phenols, tannins and lipids (Jebur et al., 2014). Hence, present study is focused towards phytochemical screening and study of anti-microbial and antiantioxidant activity of cardamom extract which may be used for the development of potent drugs. Pharmaceutical agent from cardamom will possess minimal toxicity and cost effectiveness in comparison to the compound chemically synthesized.

\section{Conclusion}

In this study, methanol extract of cardamom was examined for the presence of various phytochemicals and its antioxidant and antimicrobial activities were also evaluated. Phytochemical analysis of the extract revealed the presence of terpenoids, flavonoids and glycosides. Antimicrobial activity of cardamom extract against the following four microorganisms was evaluated: E. coli, B. pumilus, L. monocytogenes and EPEC. Maximum antimicrobial activity of the cardamom extract was found to be against EPEC, showing an inhibition zone of $20.3 \mathrm{~mm}$. Antioxidant potential of the cardamom extract was evaluated using the DPPH radical scavenging assay. The extract exhibited different degrees of antioxidant activities depending on the concentration examined. Therefore, the results of the current investigation demonstrate antimicrobial and antioxidant activities in cardamom extract and also show the possibility of various phytochemicals in the cardmom extract.

\section{ACKNOWLEDGEMENTS}

The authors are thankful to Prof. Madhu Tripathi, Head, Department of Zoology, University of Lucknow for providing the necessary facilities for research. We are also thankful to Prof. A.M Saxena, Department of Zoology, University of Lucknow and Prof. Mohammad Serrajuddin, Department of Zoology, University of Lucknow for providing the necessary facilities for preparation of cardamom extract and other laboratory facilities.

\section{REFERENCES}

Agarry, O.O., Olaleye, M.T. and Bello-Michael, C.O. (2005). Comparative antimicrobial activities of aloe vera gel and leaf. Afr. J. Biotechnol, 4(12): 1413-1414

Aiyelaagbe O.O. and Osamudiamen P.M. (2009). Phytochemical screening for active compounds in mangifera indica leaves from ibadan, Oyo State. Plant Sciences Research, 2: 11-13

Baliere C, Rince A, Delannoy S, Fach P. and Gourmelon M. (2016) .Molecular profiling of STEC and EPEC strains isolated from French coastal environments. Appl Environ. Microbiol., 22 : 271-16

Bhattacharjee, B. and Chatterjee J. (2013). Identification of proapoptopic, anti-inflammatory, anti- proliferative, anti -invasive and anti-angiogenic targets of essential oils in cardamom by dual reverse virtual screening and binding pose analysis. Asian Pac J Cancer Prev., 14(6):3735-42

Biswas, M., Haldar, P.K. and Ghosh, A.K. (2010) Antioxidant and free-radical-scavenging effects of fruits of Dregea volubilis, J Nat Sci Biol Med. Jul-Dec; 1(1): 2934

Bruneton, J. (2001). Pharmacognosy, phytochemistry, medicinal plants. 2nd edition. Lavoisier Publishers. Paris, pp 83-90

Chawla, T., Abbasi, N. I. and Tandon, A. (2014). Antimicrobial activity of spices like cloves Cardamom and Cinnamon on Bacillus and Pseudomonas.International Journal of Drug Development and Research.

Chen C.W. and Ho C.T. (1995). Antioxidant properties of polyphenols extracted from green and black teas, Journal of Food Lipids, 2 (1) : 35-46

Edeoga, H.O., Okwu, D.E. and Mbaebie, B.O. (2005). Phytochemical constituents of some Nigerian medicinal plants, Afr. J. Biotechnol, 4(7): 685-688

Grass G., Bierbaum, G., Molitor E., Gotte, N. and Antwerpen, M. (2016) Genome sequence of bacillus pumilus strain bonn, Isolated from an Anthrax-Like Necrotic Skin Infection Site of a Child. Genome Announc, 11;4 (1) : 1741-15

Hero, F., Akrayi, S. and Tikrit, P. (2012). Antibacterial effect of seed extracts of cardamom (Elettaria cardamomum) against staphylococcus aureus and proteus mirabilis. Journal of Pure Science, 17 (2) : 1813 - 1662

Islam S., Rahman A., Sheikh M., Rahman M., Mostofa, A.H. and Alam, F. (2010). In vitro antibacterial activity of methanol seed extract of elettaria cardamomum (L.) maton. Agriculturae Conspectus Scientifi cus., 75(3): 113-117

Jayawardena, N., Watawana, M.I., Jayathilaka, R.T. and Waisundara, V.Y. (2015). The antioxidant and starch hydrolase inhibitory activity of ten spices in an in vitro model of digestion: bioaccessibility of anthocyanins and carotenoids. Evid Based Complement Alternat Med., $10: 764-773$

Jebur M.H., Bnuyan, I., Yasri, A.A. and Kadhim, N.K. (2014). Antimicrobial effect of seed extracts, leaves and crude oil of cardamom (elettaria cardamomum) against different types of bacteria in hilla city, iraq, World Journal of Pharmaceutical Research, (3): 4934-4944

Kapoor I.P.S., Singh, B., Singh, G., Valery A Isidorov, Lech Szczepaniak. (2008). Chemistry, antifungal and antioxidant activities of cardamom (Amomum subulatum) 
essential oil and oleoresins. Int. J. Essent. Oil Therapeut, 2(1): 29-40

Khandelwal, K.R. (2001). Preliminary phytochemicals screening, Practical Pharmacognosy - Techniques and Experiments, 8th edn, pp-149-156

Kogure, K., Yamauchi, I., Tokumura A., Kondou K., Tanaka, N., Takaishi, Y. and Fukuzawa, K. (2004). Novel antioxidants isolated from plants of the genera Ferula, Inula, Prangos and Rheum collected in Uzbekistan. Phytomedicine, 11(7-8):645-51

Mishra, N. and Behal, K.K. (2010). Antimicrobial activity of some spices against selected microbes, International Journal of Pharmacy and Pharmaceutical Science, 2: (3)187-196

Nair, S., Nagar, R. and Gupta, R. (1998). Antioxidant phenolics and flavonoids in common Indian foods. $J$ Assoc Physicians India, 46: 708-10

Naveed, R. Hussain, I., Tawab, A., Tariq, M., Rahman, M., Hameed, S., Mahmood, M.S., Siddique, A.B., Iqbal, M. (2013). Antimicrobial activity of the bioactive components of essential oils from Pakistani spices against
Salmonella and other multi-drug resistant bacteria. BMC Complement Altern Med. 14: 265-270

Obadoni, B.O. and Ochuko, P.O. (2001). Phytochemical studies and comparative efficacy of the crude extracts of some homeostatic plants in Edo and Delta States of Nigeria. Glob.J. Pure Appl. Sci., 86: 2003-2008

Shegarfi, H., Rolstad, B., Kane, K.P. and Nestvold, J. (2016). Listeria monocytogenes infection differentially affects expression of ligands for $\mathrm{NK}$ cells and $\mathrm{NK}$ cell responses, depending on the cell type infected. J Leukoc Biol., 2: 1115-506

Srinivasan, D., Perumalsamy, L.P. and Suresh, T. (2001). Antimicrobial activity of certain Indian medicinal plants used in folk medicine. J. Ethnopharm, 1 (7): 94-99

Sultana, S., Ripa, F.A. and Hamid, K. (2010). Comparative antioxidant activity study of some commonly used spices in Bangladesh. Pakistani Journal of Biological Sciences, 1:13(7): 340-343

Umamaheswari, M. and Chatterjee, T.K. (2008). In vitro antioxidant activities of the fractions of Coccinia Grandis L. leaf extract. Afr. J Trad. Com.p Alter. Med., 5:61-73 